\title{
The Eradication of Yaws in the Sub-District of Tongkuno, District of Muna, Indonesia: Towards A Community-Based Participative Surveillance Model
}

\author{
Jasmurni Munir ${ }^{1}$, Sanihu Munir ${ }^{2}$, and Emiliano T. Hudtohan ${ }^{3}$ \\ ${ }^{\text {I}}$ (Lecturers, Graduate Study, Tri Mandiri Sakti Institute of Health Sciences, Bengkulu, Indonesia) \\ ${ }_{2,3}$ (Professor in Social Development, the Philippine Women's University, Manila, Philippines)
}

\begin{abstract}
Background: - This paper describes the findings of a research on Yaws Eradication Program in the Sub-District of Tongkuno, District of Muna, Indonesia, and to propose a Community-Based Participative Surveillance Model to improve the early detection, recording and the reporting of Yaws cases in the area. In general the study sought to explain, how aware are the people of the yaws in terms of cause, sign and symptoms, treatment, prevention and recording and reporting. The study also sought to find out the present surveillance system of the Ministry of Health in detecting, recording, and reporting of Yaws. Regarding the people belief, this study sought to find out the issues and health practices related to the spread of yaws. Finally this study proposed a community-based surveillance model that can be applied especially in the village level for early detection, monitoring, prevention and eradication of Yaws.
\end{abstract}

Methods: - The study was conducted in the Sub-District of Tongkuno, District of Muna, A total of 26 individuals participated in personal communication and interview to draw their perceptions and experiences regarding Yaws. The participants were health centre personnel, elementary school teachers, parents, sub-district officials and health cadres. The researcher drew their perceptions and experiences regarding Yaws; the cause, signs and symptoms, the treatment and its preventive measures.

Results: -. The poor and inconsistency recording and reporting were found in the surveillance of Yaws in Tongkuno. Personal communication and interview supported this problem. Only four out of fourteen (28.6\%) of health centre personnel knew Yaws including its signs and symptoms. Seven of them (50\%) identified penicillin as a treatment for Yaws. During the communication with four elementary school teachers, it found out that all of them (100\%) had no idea about the cause of Yaws as well as its sign and symptoms. They also did not know its scientific treatment. One teacher (25\%) mentioned personal hygiene as preventive measure for Yaws. The teachers admitted that they know Yaws in its secondary stage where the lesion filled with pus, burst, and ulcerate. All four parents (100\%) being interviewed did not know the cause of Yaws but recognized and mentioned it in the local name, Kandadawa. The parents were not disturbed with the disease and in the advanced stage; they brought their infected children to traditional healers for consultation and treatment. They did not know the scientific treatment and preventive measures of Yaws. All chief district officials and their staffs being interviewed (100\%) did not know the disease including its signs and symptoms. Three of them (75\%) did not know its scientific treatment. One of the chief district officials (25\%) mentioned penicillin as its treatment because he was a former Yaws case without realizing that he was infected with Yaws. In personal communication and interview with two health cadres, they could not explain the cause, signs and symptoms of Yaws. They also did not know the scientific treatment and its preventive measures.

Conclusion: - The majority of participants in personal communication and interview did not recognize Yaws including their signs and symptoms. Most of them also did not know the scientific treatment for Yaws and its preventive measures. Health centre personnel did not pay much attention to the eradication of Yaws anymore since this disease is not a priority in communicable disease control program in the health centre. In the early stage all parents (100\%) just ignore the signs and symptoms of the disease. They just let the disease grew and considered them as a sign of maturity (personal communication 2011). In this infectious stage, the parents had no intention to seek for treatment in the health centre. When the disease develops to the next stage where the lesion begins to elevate, contain pus and ulcerate, they refer their infected children to traditional healer. Traditional healer will either prepare herbal or water followed by prayer or mantra. These traditional healers also threaten the parents not to bring their children to health centre. This is the main problem why the health centre lost its control to the recording, prevention and eradication of Yaws (Munandar, personal interview, 2011). Surveillance model of Ministry of Health showed how reporting and recording activities was conducted solely by Department of Health without community participation. Poor recording and reporting result of 100\% iceberg phenomenon can be partly attributed to the absence of community participation.

Keywords: Eradication, Yaws, Surveillance model 


\section{Introduction}

The team from the Ministry of Health in 2011, found 40 new cases of yaws in the Sub-District of Tongkuno, District of Muna, Southeast Sulawesi Province, while the Health Centre Surveillance Records did not find any case. This finding was interesting because the location is adjacent the Sub-District of Lakudo where the previous cases was detected in 2002 (Munir, 2003). Nationally, yaws disease can already be controlled where the prevalence rate is less than 1 per 10,000 populations. In some provinces the disease is not even found in the last three years. However, yaws disease has not disappeared completely from the territory of Indonesia and to date still leaves focus places. In 2005 there were 5,500 cases of yaws, mostly spread in the region of Eastern Indonesia: East Nusa Tenggara, Southeast Sulawesi, Maluku, Papua and West Papua provinces. Yaws is a disease that can be eradicated because the disease is only found in human, the focus areas exist in limited districts, easily diagnosed by officers in health care units, treatment with a single injection of benzathine penicillin; no drug resistance found; germs can only live in the human body; and the relatively small number of cases. Eradication of infectious diseases is one of the programs in the fields of health, which play important role in reducing morbidity and disability from chronic diseases. One of the important activities in these programs is community-based surveillance. Surveillance of such importance in the prevention and eradication of the disease as a tool to detect disease, carefully observe the development and behavior of the disease and determine the steps to prepare for resources in eradication efforts. One of the diseases that are still found in rural communities in Southeast Sulawesi province with the effect of "backwardness" connotation is yaws. Indonesian Government has announced that the disease could be removed, since the process is very simple by using disposable benzathin penicillin injection. However, in reality, this disease remains a rural public health problem in Southeast Sulawesi Province.

\section{Methods}

The study was primarily a qualitative research designed to create a community-based participative surveillance model where the Health Center, sub-district and village officials, and the community, actively participate in the finding and reporting of new cases of Yaws in the community. The research used documentary review, communication and interview and observation methods to gain information on design. In the interview and discussions, the researcher described the perceptions and experiences of the interviewees regarding the occurrence and transmission of Yaws in the community. The subjects include Local Government officials, health centre personnel, parents, elementary school teachers, and health cadres. The researcher conducted one on one communication and interview. Additional focus group discussions were conducted with Health Center personnel and school teachers.

\section{Findings and Discussion}

In March 2011, the eradication join team from Ministry of Health, Jakarta and Provincial Health Office from Kendari found out 33 new cases of Yaws in the Sub-District of Tongkuno, District of Muna (prevalence is 25.6 per 10,000 populations). This figure is 25 higher than national standard which is 1 per 10,000 populations. Based on this finding, the researcher was interested to conduct a study in the Sub-District of Tongkuno, District of Muna to find out the problems and proposed an improved community-based surveillance model to eradicate the Yaws disease from the Southeast Sulawesi Province. When the researcher compared this finding with Integrated Surveillance Report from Tongkuno 2011, it was surprising because Integrated Surveillance Report reported no yaws case in the year 2011 (Sub-District Surveillance Recording and Reporting, 2011). It means if we only depend on the report from Integrated Surveillance Report of the health center, we will assume that there was no yaws case in Tongkuno in the year 2011. It means the prevalence is 0 (zero). This case is similar to what had happened in the sub-district of Lakudo, District of Buton (Munir, 2003) where, if only relying on routine reports of patient in the clinic through the LB1 reported by Lakudo health centers, then the iceberg phenomenon that surrounds the case in the field is 97.62 per 10,000 populations. This iceberg phenomenon is then, happened again in the sub-district of Tongkuno, District of Muna where the sub-merge huge iceberg of yaws in 2011 was covered by the zero report of Integrated Surveillance Report of Health Center. In Southeast Sulawesi Province yaws is exists every year. It puts this province into an endemic area (MOH 2007). This kind of obstacle in the reporting and surveillance weaknesses, characteristic in developing countries (Malediction, 2001).

There are six group of people participated in communication and interview with the researcher. They are: Health Centre personnel, Elementary school teachers, Parents, Sub-District and Village Officials, and Health Cadres. In the interview and discussion with health centre personnel, it found out that from 14 personnel, ten of them (71.4\%) did not know Yaws including its signs and symptoms. Seven out of fourteen (50\%) did not know the treatment of Yaws. During the interview with four elementary school teachers, it found out that all of them (100\%) had no idea about the cause of Yaws as well as its sign and symptoms. They also did not know its scientific treatment. The teachers admitted that they know Yaws in its secondary stage where the lesion filled with pus, burst, and ulcerate. Only one teacher mentioned personal hygiene as preventive measures for Yaws. 
The researcher met four parents of cases in their houses. The parents (personal interview, 2011) did not know the cause of Yaws but knew well their signs and symptoms. They call the disease Kandadawa means the Scars of Javanese. In the early stage all parents (100\%) just ignored the signs and symptoms of the disease. They accepted the disease as a common case that occurred among children as a sign of maturity (Nuriana, 2011).

The traditional procedure for this early stage was to avoid the children from taking a bath and let the disease grow. When the disease develops to the next stage where the lesion begins to elevate, contain pus and ulcerate, they refer their infected children to traditional healer. Traditional healers would treat the children by either preparing herbal or water followed by prayer or mantra (Munandar, personal interview, 2011). The healer suggested the parents not to bring the children to health centre, or else they might risk unwanted consequences. The researcher interviewed four chief district officials and their staffs. All of them (100\%) did not know the disease including its signs and symptoms. Only one (25\%) mentioned penicillin as its scientific treatment. He knew this because he is a former Yaws case who did not realize that he was infected with Yaws (Onto, 2011).

\section{Geographical overview and the yaws transmission}

\section{Conclusion}

The District of Muna has 35 sub-districts. The Sub-District of Tongkuno located at the southern part of Muna. It lies on the border between the District of Muna and the District of Buton. Based on the observation of the researcher, this border is prone to be the crossing of the yaws cases from the two districts. This observation is enhanced by the yaws programmer and supported by the Chief Sub-District of Tongkuno. She said that the family from the District of Buton visited their relatives in the District of Muna and vice versa. This family might bring the yaws case with them or the relatives in the District of Muna have been infected by yaws and transfer it to their visiting relatives. Other mode of transmission according to her is happened in the market day. The vendors from the District of Muna, who sell their products, also bring their children to the market in the District of Buton or vice versa. In the market activities, the children are infected by the children from the other district.

\section{How aware are the people of the yaws in terms of: a) Cause, b) Signs and symptoms, c) Treatment, d) Prevention, e) Recording and Reporting.}

Based on the communication and interview with the people in Tongkuno, they were not aware of the cause, signs and symptom, treatment, prevention and the way how to report the yaws case. They did not know that yaws is a communicable disease, that the case should be reported or brought to health center for medication. They did not realize that yaws is not just an ordinary itching or abscess but a lesion that grows to multiply. They did not know that Yaws begins when the germs (Treponema pertenue) penetrates the skin at a site where skin was scraped, cut, or otherwise compromised. They also did not know that this T. pertenue is transmitted from person to person.

\section{Inconsistency of Reporting and Recording}

The yaws cases are recorded and reported through: (1) Integrated Surveillance Report, (2) Monthly Health Center Report and (3) Yaws Program Report. All reports should have reported the same figure of yaws cases. However the researcher found out that all three reports issued different figures for the same disease. Integrated Surveillance Report reported no case during the year 2011. Monthly Health Center Report reported 27 yaws cases within the year 2011, while Yaws Program Report, reported 40 cases. Based on these figures, the inconsistency of the data is very clear. Integrated Surveillance Report reported no case in the entire 2011. Monthly Health Center Report reported 25 cases in April 2011 and 2 cases in July 2011. Yaws Program Report reported 33 cases in April 2011, 5 cases in May and 2 cases in July 2011. Integrated Surveillance Report should have given a most accurate figure of yaws cases in a year since surveillance is a continuous and systematic activity to monitor record and report the existence of diseases including yaws in the whole year. The successful of a diseases control program is depend on working indicator of Integrated Disease Surveillance (MOH 2004). 


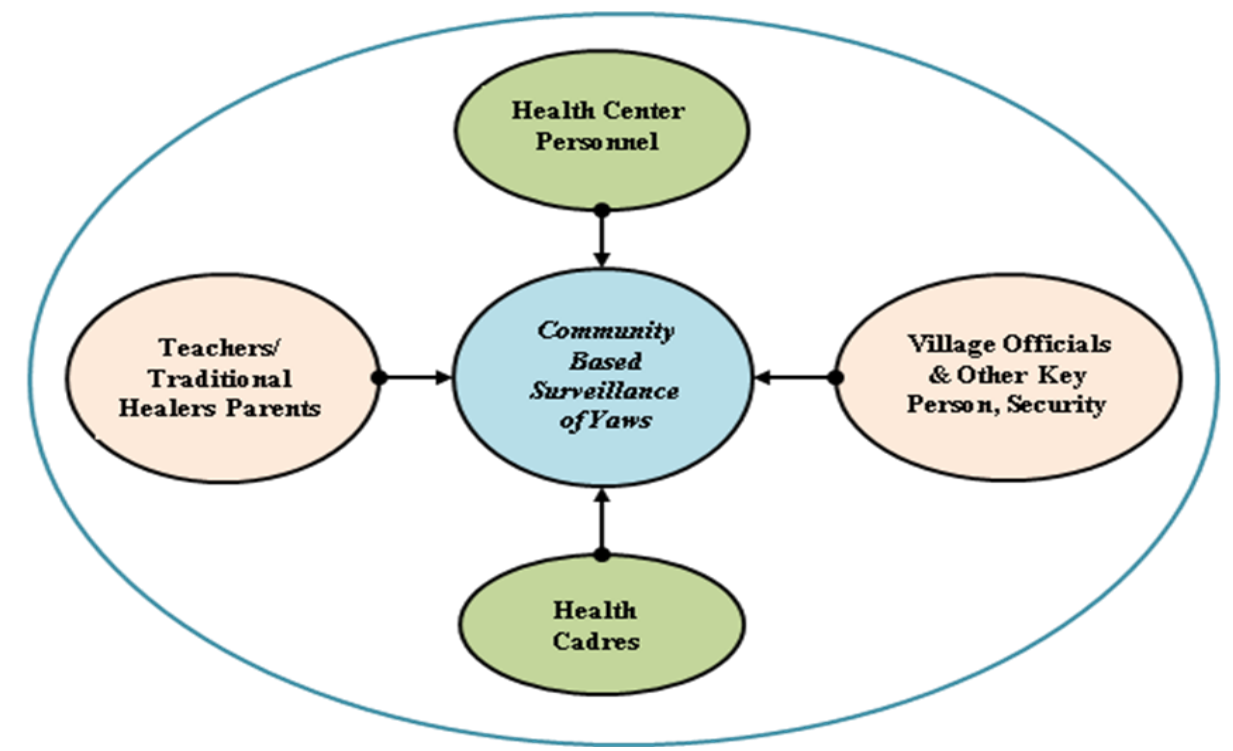

Figure 1. Conceptual Framework of Community-Based Participative Surveillance of Yaws

Table 1. Interview result on the awareness of yaws cases among health center personnel in the subdistrict of Tongkuno, (December 2011)

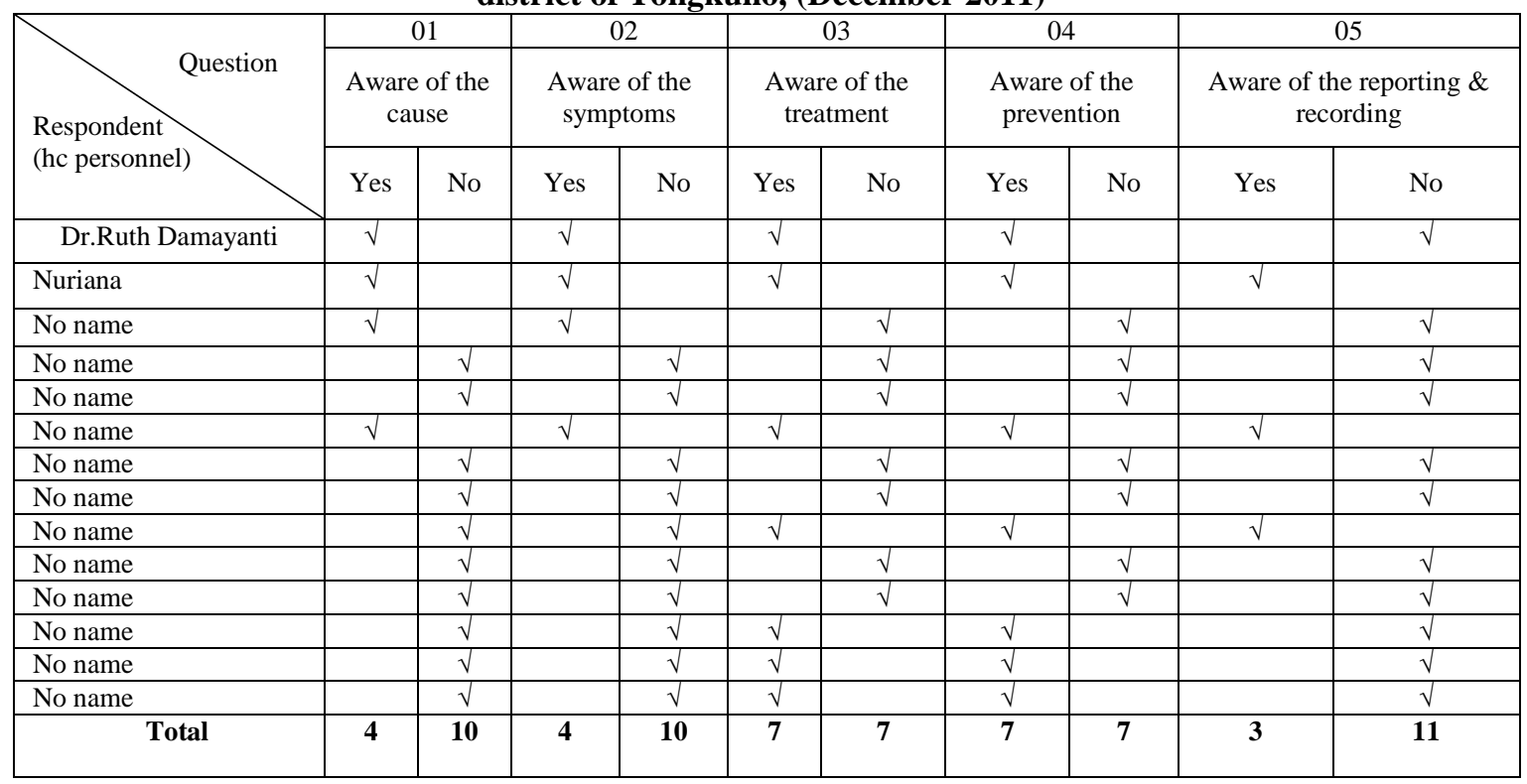

Table 2: Interview result on the awareness of yaws cases among elementary school teachers in the subdistrict of Tongkuno (December 2011)

\begin{tabular}{|c|c|c|c|c|c|c|c|c|c|c|}
\hline \multirow{3}{*}{$\begin{array}{l}\text { Respondent } \\
\text { (teachers) }\end{array}$} & \multicolumn{2}{|c|}{01} & \multicolumn{2}{|c|}{02} & \multicolumn{2}{|c|}{03} & \multicolumn{2}{|c|}{04} & \multicolumn{2}{|c|}{05} \\
\hline & \multicolumn{2}{|c|}{$\begin{array}{c}\text { Aware of the } \\
\text { cause }\end{array}$} & \multicolumn{2}{|c|}{$\begin{array}{l}\text { Aware of the } \\
\text { symptoms }\end{array}$} & \multicolumn{2}{|c|}{$\begin{array}{c}\text { Aware of the } \\
\text { treatment }\end{array}$} & \multicolumn{2}{|c|}{$\begin{array}{l}\text { Aware of the } \\
\text { prevention }\end{array}$} & \multicolumn{2}{|c|}{$\begin{array}{c}\text { Aware of the reporting \& } \\
\text { recording }\end{array}$} \\
\hline & Yes & No & Yes & No & Yes & No & Yes & No & Yes & No \\
\hline Adam Pola & & $\sqrt{ }$ & & $\sqrt{ }$ & & $\sqrt{ }$ & $\sqrt{ }$ & & & $\sqrt{ }$ \\
\hline Siti Susandra & & $\sqrt{ }$ & & $\sqrt{ }$ & & $\sqrt{ }$ & & $\sqrt{ }$ & & $\sqrt{ }$ \\
\hline Total & $\mathbf{0}$ & 4 & $\mathbf{0}$ & 4 & $\mathbf{0}$ & 4 & 1 & 3 & $\mathbf{0}$ & 4 \\
\hline
\end{tabular}


Table 3. Interview result on the awareness of yaws cases among the parents in the sub-district of Tongkuno (December 2011)

\begin{tabular}{|c|c|c|c|c|c|c|c|c|c|c|}
\hline \multirow{3}{*}{$\begin{array}{l}\text { Respondent } \\
\text { (parents) }\end{array}$} & \multicolumn{2}{|c|}{01} & \multicolumn{2}{|c|}{02} & \multicolumn{2}{|c|}{03} & \multicolumn{2}{|c|}{04} & \multicolumn{2}{|c|}{05} \\
\hline & \multicolumn{2}{|c|}{$\begin{array}{l}\text { Aware of the } \\
\text { cause }\end{array}$} & \multicolumn{2}{|c|}{$\begin{array}{l}\text { Aware of the } \\
\text { symptoms }\end{array}$} & \multicolumn{2}{|c|}{$\begin{array}{c}\text { Aware of the } \\
\text { treatment }\end{array}$} & \multicolumn{2}{|c|}{$\begin{array}{l}\text { Aware of the } \\
\text { prevention }\end{array}$} & \multicolumn{2}{|c|}{$\begin{array}{l}\text { Aware of the reporting } \& \\
\text { recording }\end{array}$} \\
\hline & Yes & No & Yes & No & Yes & No & Yes & No & Yes & No \\
\hline La Ode Hebi & $\sqrt{ }$ & & & $\sqrt{ }$ & & $\sqrt{ }$ & & $\sqrt{ }$ & & $\sqrt{ }$ \\
\hline No name & $\sqrt{ }$ & & & $\sqrt{ }$ & & $\sqrt{ }$ & & $\sqrt{ }$ & & $\sqrt{ }$ \\
\hline No name & $\sqrt{ }$ & & & $\sqrt{ }$ & & $\sqrt{ }$ & & $\sqrt{ }$ & & $\sqrt{ }$ \\
\hline $\begin{array}{l}\text { Total } \\
\end{array}$ & 4 & $\mathbf{0}$ & $\mathbf{0}$ & 4 & $\mathbf{0}$ & 4 & $\mathbf{0}$ & 4 & $\mathbf{0}$ & 4 \\
\hline
\end{tabular}

Table 4. Interview result on the awareness of yaws cases among sub-district officials in the sub-district

\begin{tabular}{|c|c|c|c|c|c|c|c|c|c|c|}
\hline \multicolumn{11}{|c|}{ of Tongkuno (December 2011) } \\
\hline \multirow{3}{*}{$\begin{array}{l}\text { Respondent } \\
\text { (C.D. officials) }\end{array}$} & \multicolumn{2}{|c|}{01} & \multicolumn{2}{|c|}{02} & \multicolumn{2}{|c|}{03} & \multicolumn{2}{|c|}{04} & \multicolumn{2}{|c|}{05} \\
\hline & \multicolumn{2}{|c|}{$\begin{array}{l}\text { Aware of the } \\
\text { cause }\end{array}$} & \multicolumn{2}{|c|}{$\begin{array}{l}\text { Aware of the } \\
\text { symptoms }\end{array}$} & \multicolumn{2}{|c|}{$\begin{array}{l}\text { Aware of the } \\
\text { treatment }\end{array}$} & \multicolumn{2}{|c|}{$\begin{array}{l}\text { Aware of the } \\
\text { prevention }\end{array}$} & \multicolumn{2}{|c|}{$\begin{array}{l}\text { Aware of the reporting \& } \\
\text { recording }\end{array}$} \\
\hline & Yes & No & Yes & No & Yes & No & Yes & No & Yes & No \\
\hline Abidin Onto, SP & & $\sqrt{ }$ & & $\sqrt{ }$ & $\sqrt{ }$ & & & $\sqrt{ }$ & & $\sqrt{ }$ \\
\hline No name & & $\sqrt{ }$ & & $\sqrt{ }$ & & $\sqrt{ }$ & & $\sqrt{ }$ & & $\sqrt{ }$ \\
\hline Total & & 2 & & 2 & $\mathbf{1}$ & 1 & & 2 & & 2 \\
\hline
\end{tabular}

Table 5. Interview result on the awareness of yaws cases of the health cadres in the sub-district of Tongkuno (December 2011)

\begin{tabular}{|c|c|c|c|c|c|c|c|c|c|c|}
\hline \multirow{3}{*}{$\begin{array}{l}\text { Respondent } \\
\text { (cadre) }\end{array}$} & \multirow{2}{*}{\multicolumn{2}{|c|}{$\begin{array}{c}01 \\
\begin{array}{c}\text { Aware of the } \\
\text { cause }\end{array}\end{array}$}} & \multicolumn{2}{|c|}{02} & \multicolumn{2}{|c|}{03} & \multicolumn{2}{|c|}{04} & \multicolumn{2}{|c|}{05} \\
\hline & & & $\begin{array}{r}\text { Awa } \\
\text { syr }\end{array}$ & $\begin{array}{l}\text { the } \\
\mathrm{ms}\end{array}$ & $\begin{array}{r}\mathrm{Aw} \\
\operatorname{tr}\end{array}$ & $\begin{array}{l}\text { f the } \\
\text { ent }\end{array}$ & $\begin{array}{l}\text { Aw } \\
\text { pre }\end{array}$ & $\begin{array}{l}\text { the } \\
\text { on }\end{array}$ & Aware & orting \& \\
\hline & Yes & No & Yes & No & Yes & No & Yes & No & Yes & No \\
\hline WD Siti Halifah & & $\sqrt{ }$ & & $\sqrt{ }$ & & $\sqrt{ }$ & & $\sqrt{ }$ & & $\sqrt{ }$ \\
\hline No name & & $\sqrt{ }$ & & $\sqrt{ }$ & & $\sqrt{ }$ & & $\sqrt{ }$ & & $\sqrt{ }$ \\
\hline
\end{tabular}

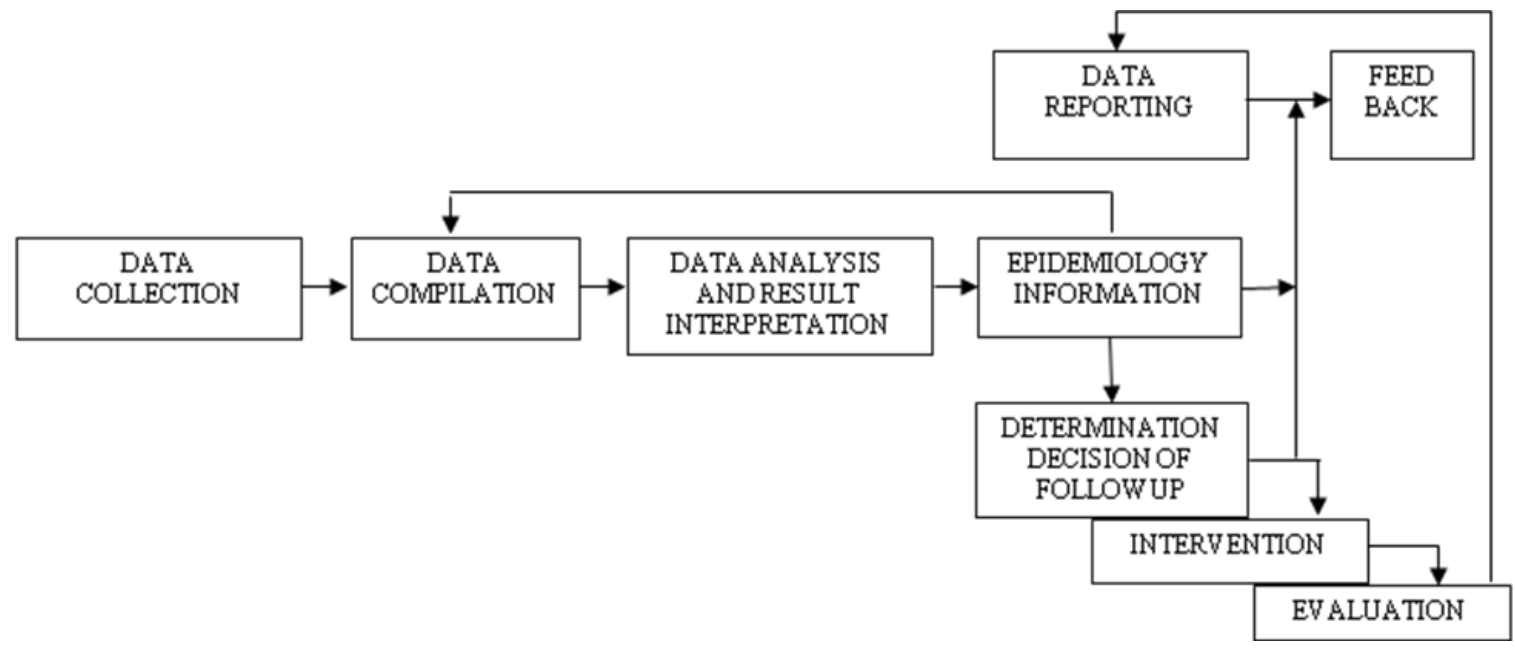

Figure 2: Flow chart of epidemiologic surveillance of the Ministry of Health.

\section{Recommendation}

Based on the findings and conclusion, the researchers recommend the followings:

1. Surveillance of yaws should be conducted in equal partnership among stakeholders.

2. The health center personnel should be well trained in detecting, examining and treating the yaws cases in order to do their job professionally.

3. The Health center should launch a campaign to awaken the community to realize the nature, cause, signs and symptoms, prevention and the treatment of yaws. 
4. Health center should educate and enlighten the traditional healer to actively participate in the eradication of yaws through their influence.

5. There should be a community organizing intervention model to be applied in the prevention and eradication of Yaws in Tongkuno.

6. Provincial Health Office should establish a join-team of two districts i.e. Buton and Muna to conduct intensive case finding to eliminate the Yaws case from the districts.

7. The need for community-based participative surveillance model for yaws eradication to provide accurate, reliable and timely yaws information for the proper planning and decision making

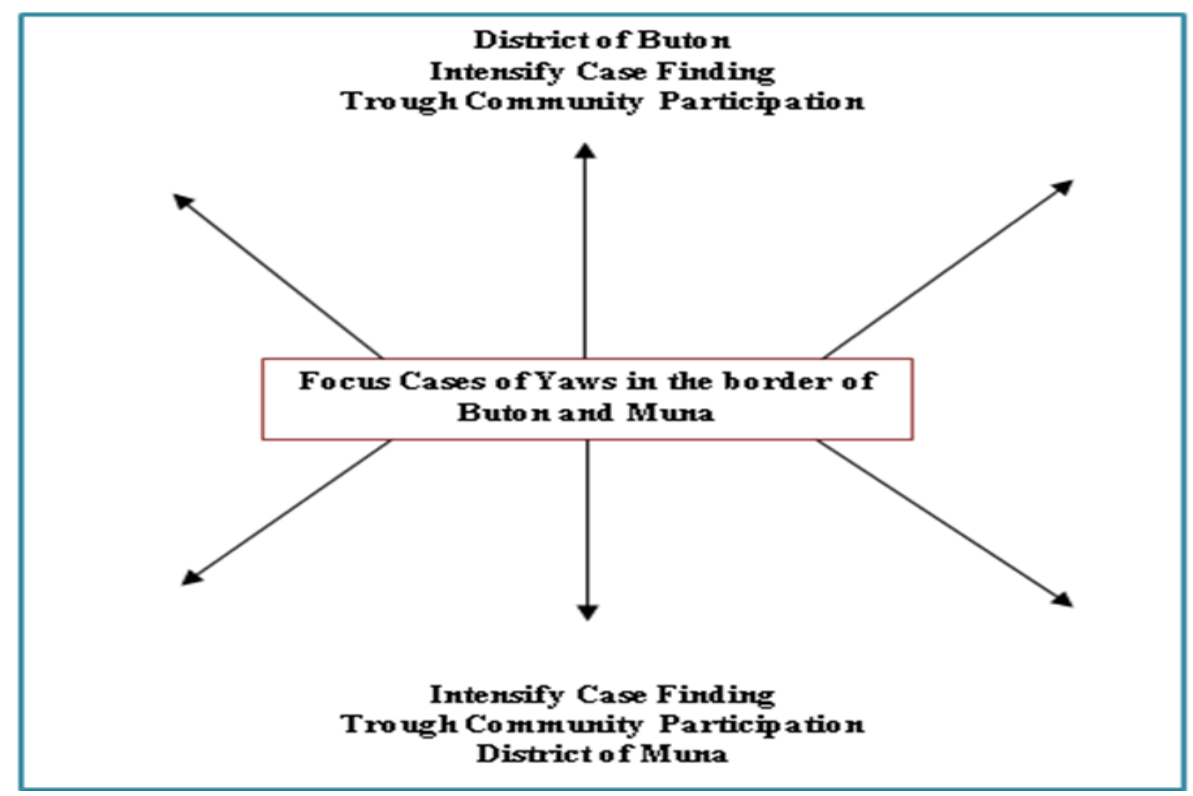

Figure 3. Yaws eradication join-team strategy in the District of Buton and Muna

Table 6. FCASI intervention model applies in the community organizing in yaws surveillance system for the people in Tongkuno

\begin{tabular}{|c|c|c|c|}
\hline Apathy Stage & Dependency Stage & Pre Critical Stage & Liberation Stage \\
\hline $\begin{array}{l}\text { "No Problem" , } \\
\text { Yaws is a common } \\
\text { itching or abscess } \\
\text { that will not cause } \\
\text { death }\end{array}$ & $\begin{array}{l}\text { "Recognition of problem but } \\
\text { solution is outside", } \\
\text { Yaws is a health center } \\
\text { business and they are the } \\
\text { one responsible to handle it }\end{array}$ & $\begin{array}{l}\text { "Recognition that man is part of } \\
\text { the solution" People realize } \\
\text { the existence of yaws problem in } \\
\text { their village and willing to work } \\
\text { out to solve it }\end{array}$ & $\begin{array}{l}\text { "He cares and commits himself to } \\
\text { transform society" Community leaders } \\
\text { commit themselves to the } \\
\text { transformation of their community from } \\
\text { yaws endemic village to yaws free } \\
\text { village }\end{array}$ \\
\hline
\end{tabular}

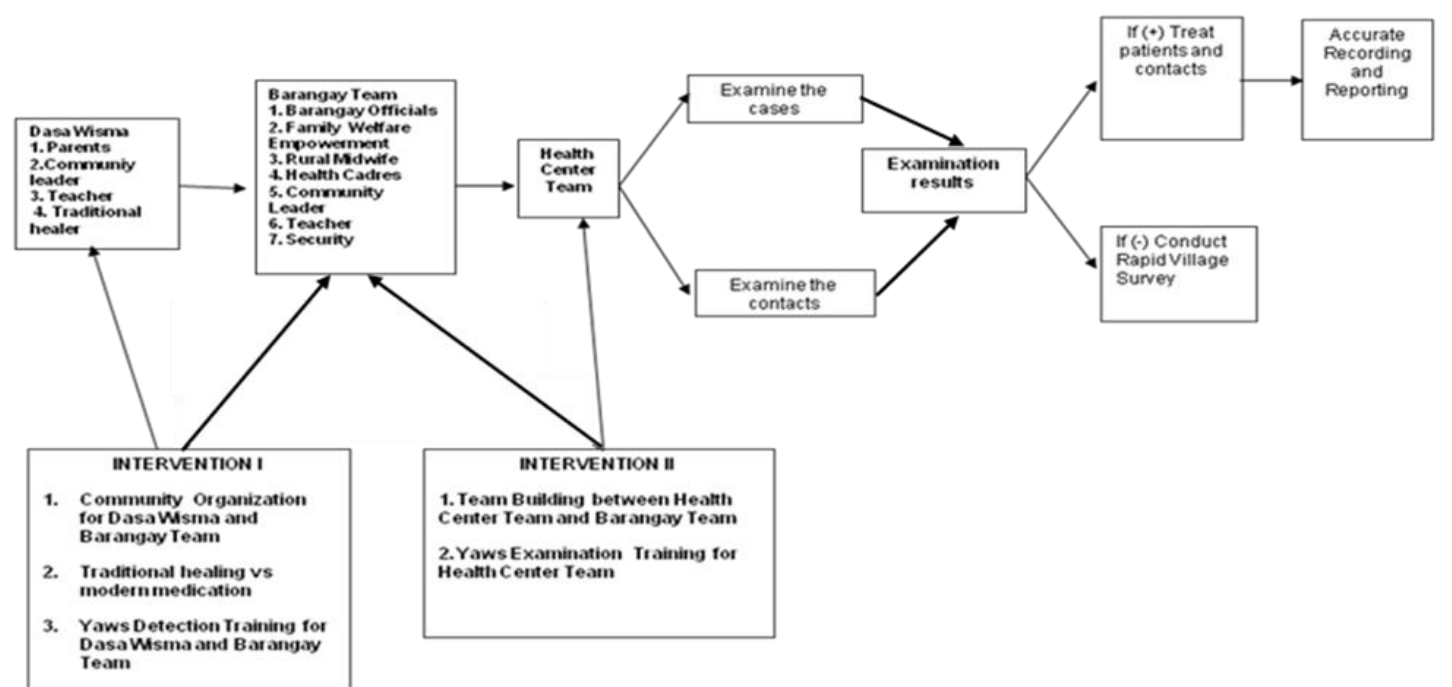

Figure 4. Recommended community-based participative surveillance model for yaws eradication program in Tongkuno, Indonesia. 
Biographical Details:

\section{Bibliography}

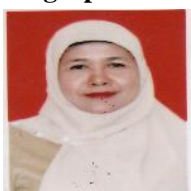

Dr, Jasmurni Munir is a lecturer of public health at graduate study program, Tri Mandiri Sakti Institute of Health Sciences, Bengkulu, Indonesia and visiting lecturer for public health at Mandala Waluya Institute of Health Science, Kendari Indonesia. Jasmurni Munir has 30 years teaching experience in surveillance and epidemiology in the school of nursing, Academy of Sanitation Technology and College of Public Health in Southeast Sulawesi Province. She is also a TB and AIDS educator and one of the Yaws experts in Indonesia. She started her career as Chief Communicable Disease Control at the City of Sawahlunto, West Sumatera, Indonesia in 1980. In 1983 she started her teaching career at the school of nursing in Kendari Indonesia. At present she is teaching Public Health at graduate study Tri Mandiri Sakti Institute of Health Sciences in Bengkulu. In line with her expertise in Yaws, Jasmurni Munir has conducted two researches in Yaws, Factors Affecting the Occurrence of Yaws on Under-fifteen in the Rural of Lolibu, District of Buton, Indonesia, 1991, and Uncover Iceberg Phenomenon of Yaws in the Rural of Dariango, District of Buton, Indonesia, 2003

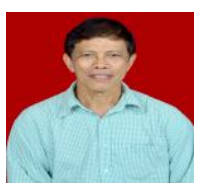

Dr. Sanihu Munir is a lecturer of Nursing and Public Health at Mandala Waluya Institute of Health Sciences, Kendari, Indonesia and a visiting lecturer at Tri Mandiri Sakti Institute of Health Sciences, Bengkulu, Indonesia. Sanihu Munir has 33 years teaching experience in English for nursing, Epidemiology and Statistics at the department of nursing and public health. He is also a nursing education consultant at Kolaka Nursing Academy, Kolaka Indonesia, and Tri Mandiri Sakti Institute of Health Sciences in Bengkulu, Indonesia. He started his career as Chief of Sanitation section at Kendari District Health Office in 1971. In 1980, he started his teaching career in the school of nursing in Kendari, Indonesia. At present he is teaching English for nursing, epidemiology and statistics at the Department of Nursing and Public Health, Mandala Waluya Institute of Health Sciences and a visiting lecturer at Tri Mandiri Sakti Institute of Health Sciences. As a lecturer and researcher, Sanihu Munir has conducted a research on The Perception of Nursing Students and Their Parents towards the Employment after Graduating in Kolaka and Bengkulu, Indonesia in 2010. He also conducted a research on Surveillance Model in the Eradication of Yaws in the District of Muna, Indonesia with Jasmurni Munir in 2011.

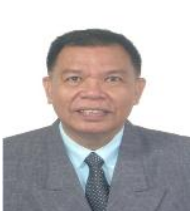

Dr. Emiliano T. Hudtohan is a professor and lecturer of Social Development at the Philippine Women's University, Manila, Philippines and also teaching Organizational Development, Business Ethics and Corporate Social Responsibility at De La Salle University, Manila, Philippines. Emiliano T. Hudtohan has more than 40 years experience since 1967 until now in the field of Social Development and Business Development and Management. He is also a columnist in the Philippine national newspapers; Manila Standard Today, Manila Times and Business Mirror. He has started his career in 1978 as Assistant Project Manager at USAID Philippines. In 1982 he was assigned as Assistant President of Malaya Insurance Company. In 1991 he was elected as Senior Management Consultant at Metrobank Philippines. At present, he is teaching at graduate program in Social Development and Business at the Philippine Women University, De La Salle University Manila, Far Eastern University and San Beda College in Manila. As a columnist and researcher, Dr Hudtohan has many papers published in newspapers and journals among others; The Law of Attraction, Manila Standard Today, 12 Januari, 2009, Ethic, Etiquette and Aesthetics. The Philippine Educational Forum, Philippine Women's University. Vol. 19, No. 2, September 2006.

\section{References}

[1] Benenson, A.S Control of Communicable Disease in Man, Washington DC: American Public Health Association, 1990.

[2] Elder JP, Geller ES, Hovel MF, Mayer JA, Motivating Health Behavior, New York, Delmar Publisher Inc, 1994.

[3] G.C. Cook, MD., DSc FRCP Fracp FLS, Manson's Tropical Diseases, London: WB Sauders Company Ltd, 1993

[4] Glanz K, Lewis FM, Rimer BK,. Health Behavior and Health Education:Theory Research and Practice, Second Edition, San Fransisco: Jossey-Bass Publishers, 1997.

[5] Gochman OS,. Health Behavior: Emerging Research Perspective, New York: Plenum Press. 1988

[6] Greenbaum TL The Practical Handbook and Guide to Focus Group Research, Lexington, D.C: Heath and Company, 1988

[7] Halperin W, Baker EL Public Health Surveillance, New York: Van Nostrand Reinhold, 1992

[8] Klein NC, Yaws, New York: CME, Section 2. 2001

[9] Notoatmodjo, Soekidjo, Pengantar Perilaku Kesehatan Masyarakat, Jakarta: 1989

[10] Perine PL, Hopkins DR, Niemel PLA, John RKSt., Causse G, Antal GM,. Handbook of Endemic Treponematoses, Geneva: World Health Organization, 1984

[11] Ratgono A Surveilans Epidemiologi Bagi Petugas Puskesmas, Surabaya: Dinas Kesehatan Propinsi Jawa Timur, 2002.

[12] Simons JA, Irwin DB, Dnnnien BA, Maslow Hierarchy of Need, New York: West Publishing company (Internet), 1987.

[13] Singarimbun, M.dan Effendi,S Metode Penelitian Survei. Jakarta: LP2ES, 1986.

[14] Suyanto, Bagong, dkk, Metode Penelitian Sosial. Surabaya: Airlangga University Press, 1995

[15] Soedarsono Petunjuk Pemberantasan Penyakit Frambusia Untuk Petugas Kesehatan, Jakarta: Departemen Kesehatan, 1971

[16] Soegiyono Metode Penelitian Administrasi. Bandung: Alfabeta, 2000.

[17] White AT Why Community Participation?, Geneve: United Nations Children's Fund (UNICEF), 1982

[18] Departemen Kesehatan RI Direktorat Jenderal PPM \& PLP, 1999. Epidemiologi Fenyakit Frambusia, Jakarta.

[19] Departemen Kesehatan RI, Direktorat Jenderal PPM \& PLP, 1986. Gejala Frambusia Dalam Gambar, Jakarta.

[20] Departemen Kesehatan RI, 1981. Himpunan Nomenklatur Bidang Kesehatan, Jakarta,

[21] Badan Pusat Statistik (BPS) Kabupaten Muna Tahun 2009, 2010. Kabupaten Muna Dalam Angka, Raha.

[22] Direktorat Jenderal PPM \& PLP Departemen Kesehatan R.1., hal. 2-5, 2000. Petunjuk Teknis Intensfikasi Unit Surveilans Dinas Kesehatan Kàbupaten/Kota, Jakarta:

[23] Departemen Kesehatan R.I., Direktorat Jenderal Pembinaan Kesehatan Masyarakat 1997. Petunjuk Pengisian Formulir Pelaporan SP2TP: Buku II, Seri C, Jakarta.

[24] Departemen kesehatan R.1., Direktorat Jenderal Pembinaan Kesehatan Masyarakat, 1997. Pedoman Sistem Informasi Manajemen Puskesmas: Sistem Pencalatan dan Pelaporan Terpadu Puskesmas: Buku 1, Jakarta.

[25] Departemen Kesehatan RI, Direktorat Jenderal PPM-PLP, Direktorat Epidemiologi dan Imunisasi, 1994. Pedoman Surveilans Epidemiologi Penyakit Menular, Jakarta.

[26] Eradication Programme, 2003. Report Of Active Search, Baroda, Skin \& Veneral Disease Government Medical College (Internet),

[27] Anselmi, M., Moreira, J.-M., Caicedo, C., Guderian, R. and Tognoni, G. (2003), Community participation eliminates yaws in Ecuador. Tropical Medicine \& International Health, 8: 634-638. doi: 10.1046/j.1365-3156.2003.01073.x

[28] Control of yaws 2003., 50 Years of WHO in South East Asia (Internet), hal.1

[29] Davis, Charles Patrick, Yaws, Medicine Net.com, 2011, http://www.medicinenet.com/yaws/article.htm

[30] Departemen Kesehatan RI, Direktorat Jederal PPM \& PLP, 2007. Pedoman Eradikasi Frambusia, Jakarta, 
[31] Departemen Kesehatan RI, Direktorat Jenderal PPM \& PLP,1986, Gejala Frambusia Dalam Gambar, Jakarta.

[32] Departemen Kesehatan RI, Direktorat Jenderal PPM \& PLP.1990, Tabulasi Pemberantasan Penyakit Frambusia dan ,Jadwal Kegiatan Pemberantasan Penyakit Frambusia, Jakarta,

[33] Departemen Kesehatan RI.1972, Perundang-undangan di Bidang Kesehatan, Jakarta,

[34] Departemen Kesehatan RI.1984, Sistem Kesehatan Nasional (Cetakan Kedua), Jakarta,

[35] Departemen Kesehatan RI.1989, Rencana Pembangunan Lima Tahun Bidang Kesehatan, Jakarta,

[36] Departemen Kesehatan, Direktorat Jenderal PPM \& PLP 2004, Pedoman Penyelenggaraan System Surveillance Epidemiologi Penyakit Menular dan Penyakit Tidak Menular Terpadu, Jakarta,

[37] Departernen Kesehatan RI, Direktorat Jenderal PPM \& PLP.1999, Pedoman Pemberantasan Penyakit Frambusia, Jakarta,

[38] Dinas Kesehatan Kabupaten Buton, 2001 \& 2002, Laporan Hasil Kegiatan pemberantasan Penyakit Frambusia Kabupaten Buton Tahun 2001 dan 2002, Bau-Bau Buton,

[39] Dinas Kesehatan Kabupaten Buton, 2002. Laporan Puskesmas Kecamatan Lakudo Tahun, Lakudo.

[40] Dinas Kesehatan Kabupaten Muna. 2010. Profil Kesehatan Kabupaten Muna. Raha.

[41] Dinas Kesehatan Provinsi Sulawesi Tenggara, 2001 \& 2002, Laporan Hasil Pelaksanaan Program Pemberantasan Penyakit Frambusia Tahun $2001 \& 2002$, Kendari,

[42] Dowdle, Walter R, The Principles of Disease Elimination and Eradication, CDC MMWR, 1999, http://www.cdc.gov/mmwr/preview/mmwrhtml/su48a7.htm.

[43] Elder JP, Geller ES, Hovell MF, Mayer JA. 1994. Motivating Health Behavior, New York, Delmar Publisher Inc.

[44] Halperin W, Baker EL. 1992. Public Health Surveillance Surveillance, New York, Van Nostrand Reinhold, 1p. Http://en.wikipedia.org/wiki/Community.

[45] Kasl, S.V and Cobb, S 1966. Preventive Health Behavior. http://www.enotes.com/preventive-health-behavior-reference/preventivehealth-behavior

[46] Mafart, Bertrand, Goundou: a historical form of yaws, Department of Medical History, The Lancet, Vol. 360, 2002, http://bertrand.mafart.free.fr/paleoanthropology_paleopathology full text mafart/goundou.pdf

[47] McQueen, David V. Illness and Sick-Role Behavior, http://www.enotes.com/illness-sick- role-behavior-reference/illness-sickrole-behavior

[48] Oakley and Marsden, Undrstanding Community Participation, 1987, http://lyceumbooks.com/pdf/Effective_ Community_P Chapter_02.pdf

[49] Oum, Sophal, Daniel Chandramohan, Sandy Cairncross, Community-based surveillance: a pilot study from rural Cambodia, Vol. 10, Issue 7, Tropical Medicine \& International Health, 2005, http://onlinelibrary.wiley.com/doi/10.1111/j.13653156.2005.01445.x/full

[50] Paul, Samuel. Community Participation in Development Project, World http://wwwwds.worldbank.org/servlet/WDSContentServer/WDSP/IB/1999/09/21/000178830_98101903572729/Rendered/PDF/multi_page.pdf

[51] Rinaldi, Andrea. Yaws: A Second (and Maybe Last?) Chance for Eradication, PLoS Neglected Tropical Diseases, 2008 http://www.plosntds.org/article/info\%3Adoi\%2F10.1371\%2Fjournal.pntd.0000275 